\title{
Por uma teoria dos emergentes: países emergentes e segurança nas relações internacionais
}

\author{
Wellington Pereira Carneiro'
}

\section{Resumo}

$\mathrm{O}$ artigo analisa as limitações das teorias de relações internacionais que tendem a reduzir os fenômenos sistêmicos àqueles ocorridos apenas nas interações centrais no sistema. Alerta para a pouca elaboração dos fenômenos periféricos ou de transição e para uma nova recomposição multipolar do mundo atual. $\mathrm{O}$ artigo tem o escopo de prover uma abordagem inicial dos diferentes tipos de emergência no cenário internacional, concentrando-se no aspecto da acumulação de poder e influência no âmbito das questões relacionadas à segurança internacional inclusive a reforma do conselho de segurança, e o papel de países emergentes como o Brasil, África do Sul, Índia e Rússia principalmente. O caráter re-emergente da Rússia e suas dinâmicas particulares são analisadas separadamente.

Palavras-chave: Segurança internacional. Conselho de Segurança. Países emergentes. Pós-guerra fria. Concentração de poder.

\section{Introdução}

Em agosto de 1991, o Presidente da República Federativa Soviética Russa, Boris Yeltsin subia num tanque do Exército soviético, em frente ao parlamento da União, entre as margens do Rio Moscou e a Avenida Novaya Arbat, e decretava, com aquele ato simbólico, o fim do poderio militar da União Soviética, que havia prevalecido desde o fim da Segunda Guerra Mundial. Em 31 de dezembro, menos

\footnotetext{
${ }^{1}$ Wellington Pereira Carneiro, Mestre em Direito Internacional dos Direitos Humanos pela Universidade de Oxford, Reino Unido, em Direito Internacional Público pela Universidade "Drujby Narodov", Moscou; Doutorando em Relações Internacionais pela UnB; Professor de Proteção Internacional dos Direitos Humanos no Centro Universitário de Brasília - UniCEUB, e Oficial de Proteção do Alto Comissariado da ONU para Refugiados - ACNUR no Brasil.
} 
de seis meses depois, desaparecia a segunda maior potência hegemônica do século XX. Em outubro de 1993, os mesmos tanques bombardeavam o mesmo parlamento a mando do mesmo Boris Yeltsin para enterrar sobre os seus escombros os últimos focos de resistência do poder soviético.

O fim da Guerra Fria trouxe grandes transformações estruturais no cenário da segurança internacional e possibilitou o aparecimento dos chamados países emergentes, aspirantes a serem tomadores de decisões em matéria de segurança internacional, reivindicando espaços de poder abandonados pelo desaparecimento súbito de um grande 'hegemon'.

$\mathrm{Na}$ tentativa de definição de emergentes, as teorias das relações internacionais não podem definir se é o poder que abomina o vazio, ou se é este que atrai inexoravelmente novos poderes, sejam eles quais forem. A emergência não está predestinada a ser estabilizadora ou desestabilizadora da segurança internacional.

No entanto, a academia nos países industrializados, especialmente nos Estados Unidos e na Europa, não tem se ocupado do fenômeno da emergência de novas potências, ainda que isso venha, possivelmente, determinar os rumos da reconfiguração da ordem internacional num futuro mundo multipolar. Para os realistas, isso significaria mais instabilidade e, particularmente para John Merchaimer, o formulador do realismo ofensivo, a multipolaridade trairia inexoravelmente mais insegurança às relações internacionais. Até que ponto isso não é apenas um ponto de vista hegemônico, uma vez que o unilateralismo será menos possível, menos aceitável e a construção do consenso será um pré-requisito da estabilidade internacional? Não há evidência histórica de que a multipolaridade seja instável por natureza. Já Alexander Wendt acha que a anarquia é o que os estados fazem dela.

Já para a escola inglesa, a consolidação da sociedade internacional é um processo que vem se desenvolvendo e a interdependência se aprofunda como parte inevitável deste curso dos acontecimentos.

No entanto, a teoria das relações internacionais oscila entre as interpretações mais sociológicas e multilateralistas do construtivismo e do liberalismo institucional por um lado e a reafirmação do realismo, agora mais exacerbado em seus pressupostos do interesse nacional, o temor e a anarquia do realismo ofensivo de Merchaimer que, ainda que não seja simpático à maioria da academia brasileira 
mais inclinada a interpretações multilateralistas, apresenta uma coerência interna respeitável.

Os dias do imediato pós-Guerra Fria, com as generalizações idealistas e triunfalistas de Francis Fukuyama (1989), viram o otimismo exacerbado expressar-se na ideia do fim da história às vésperas dos pesadelos de Iugoslávia e Ruanda. Esses dias, felizmente, ficaram para trás. Igualmente as respostas pouco profundas e igualmente generalizantes de Samuel Huntington (1997) com o choque de civilizações, também terminaram por perder força, e temos a impressão de estar voltando a aproximar-nos dos processos reais e das dinâmicas concretas que se dão nas relações internacionais contemporâneas. Ainda que essas elaborações tenham trazido contribuições importantes uma vez que, por exemplo, a emergência das identidades culturais e nacionais no pós-Guerra Fria seja um elemento importante da nova realidade, está longe de determinar um choque de civilizações. Ou mesmo no caso de Fukuyama, em que o liberalismo tenha alcançado um nível de consenso sem precedentes, está longe de determinar uma mudança tão radical na (o fim) história da humanidade.

Com alívio, vemos o rigor científico e o cuidado metodológico voltarem aos textos e obras que norteiam o debate sobre as relações internacionais. Não obstante, a teoria das relações internacionais continua padecendo do mal do centralismo, de certa megalomania política ocidental, da obsessão pelo papel dos países centrais e as dinâmicas no centro do sistema, dos impérios que perecerão, da ascensão e queda das grandes potências, da tragédia da política dos grandes poderes.

Em algum momento da história, os grandes não foram tão grandes e talvez, entender a ascensão pode ser uma forma de entender as razões da queda. Entender a periferia pode ser uma forma de localizar o centro, entender os mecanismos da estabilidade e da instabilidade e suas origens sistêmicas.

A questão colonial, um tema periférico jogou um papel importante na instabilidade que gerou a primeira grande guerra; a falta de cooperação, o chamado consenso entre vencedores e vencidos; a humilhação da Alemanha punida e empurrada ao abismo da hiperinflação e da desordem interna, também foi importante no surgimento do nazismo e no rearmamento que resultou na II Grande Guerra. Justamente a emergência da Alemanha, a partir da unificação, desestabilizou o equilíbrio hegemônico europeu, tanto econômico como militar. 
O abandono do estudo dos processos periféricos não é científico. A relação entre periferia e centro é dinâmica e inter-relacionada. O conceito de "forças profundas" de Pierre Renouvin mantém sua plena vigência uma vez que nem sempre os processos mais visíveis são os que determinam o curso dos acontecimentos. Nesse sentido, foi que os processos intestinos no seio da União Soviética determinaram seu fim e não o embate entre as grandes potências, marcando o grande fracasso histórico do realismo como instrumental para entender as relações internacionais. Desde então, navegamos em águas revoltas, com pouca visibilidade e pouco alcance.

Nesse sentido, é louvável a tentativa de Parag Khanna de entender os emergentes em seu livro "O Segundo Mundo" publicado em 2008. No entanto, a generalização, um tanto mal polida, e a inexplicável ausência da Índia, (como alguém pode ignorar a Índia?), deixam a desejar. Além do mais, ele está preocupado com a emergência de, supostamente, um novo império, a China.

Na América Latina, o argentino Carlos Escudé, com seu realismo periférico, procurou entender as dinâmicas do alinhamento. Infelizmente, com a crise de 2001, que poderíamos dizer, foi produto do excessivo alinhamento com as receitas neoliberais ditadas pelo consenso de Washington, tampouco venceu o escrutínio da realidade.

A escola brasileira procurou elaborar uma teoria que olhasse o mundo desde uma perspectiva mais próxima à nossa realidade e assim, não só contribuir com a localização coerente do Brasil nas relações internacionais, mas contribuir com o conhecimento em geral, uma vez que fornece um olhar inovador e uma perspectiva original das relações internacionais (CERVO, 2007). Ao identificar o desenvolvimento como o fator que marca a continuidade da política externa brasileira desde os anos 30, pelo menos, já fornece um espelho surpreendente. Com efeito, mesmo no marco da teoria da dependência, que foi, em parte, superada, a busca do desenvolvimento é a linha de continuidade que une os governos militares e muitos dos marxistas da dependência, com os neoliberais dos anos 90 . Um retrato histórico revelador.

Em 2004, a cúpula América do Sul - Países Árabes, ASPA, teria tirado o sono de qualquer um que acreditasse no choque de civilizações, devido às abismais 
assimetrias culturais entre os países participantes. No entanto, a cúpula foi um sucesso e se repetiu em 2009, em Doha. O saldo foi extremamente positivo de um aumento extraordinário do comércio e da cooperação entre esses países culturalmente tão díspares. O Brasil registrou um aumento de $150 \%$ no comércio com os países árabes, ultrapassando o bilhão de dólares (exportações $621 \mathrm{mi} ; 784$ importações em 2008) (FLECK, 2009, p. 18). Qual foi o papel do aspecto SulSul nessa aproximação? Ou seja, existe vida na periferia e ela pulsa. No entanto, quem estuda esses processos? Se as academias dos países do sul não o fizerem, dificilmente alguém o fará.

Já se disse que todo olhar é uma paisagem e que cada qual vê o mundo com seus próprios olhos. Portanto, a elaboração sobre os temas que mais interessam aos países emergentes como o Brasil é uma necessidade inescapável. O fenômeno da emergência é bastante complexo e o Brasil está inserido nele, sem receitas, nem teoria (que não tenha receitas é bom, que não tenha teoria, nem tanto). Ele tem dinâmicas próprias numa época em que as dinâmicas são mutantes, num mundo vivendo a pior crise financeira desde a quebra da bolsa em 1929, conflitos genocidas, crise climática e incerteza.

O presente ensaio não passa de um parco olhar sobre a dúvida, um passo tímido. No entanto, também podemos dizer que todo passo é uma descoberta.

\section{0 que são países emergentes?}

O propalado mundo unipolar, em matéria de segurança internacional, não chegou a existir completamente. O espaço político-militar, ocupado pela ex-União Soviética nas relações de segurança coletiva, jamais foi completamente ocupado pelos Estados Unidos. O formidável poderio militar dos Estados Unidos não foi capaz de resolver as novas dinâmicas dos conflitos gerados no pós-Guerra Fria.

O surgimento dos emergentes é uma demonstração cabal desse fato, uma vez que eles ocupam espaços de poder que a única superpotência do globo não pôde, não pode, ou não quer ocupar. Nesse sentido, o estudo elaborado pela teoria do neoliberalismo nas relações internacionais caracteriza este momento, em que as instituições prevalecem e preservam a estabilidade numa situação de 
declínio da hegemonia (KEOHANE, 2005). No entanto, a novidade pouco prevista foi o rápido declínio e desaparecimento quase súbito da União Soviética, que praticamente, em menos de uma década, desapareceu completamente do cenário das relações internacionais de segurança coletiva. O declínio repentino e a incapacidade do poderio americano de expandir-se rapidamente criaram efetivamente um hiato de poder no sistema de segurança internacional que foi ocupado por atores não-estatais, estabelecendo áreas de anarquia total ou relativa, ou foram sendo ocupados pelos emergentes, já em consenso, explícito ou tácito com o único superpoder restante.

No entanto, este processo tem sido bastante complexo, e a política externa dos Estados Unidos não reconheceu inicialmente sua impossibilidade de estabelecer uma nova ordem: uma estabilidade unipolar.

\section{Da instabilidade bipolar à desordem unipolar}

Os Estados Unidos moldaram a ordem econômica e social do mundo ocidental no pós-guerra. Para isso, criou um sistema de segurança para manter a relativa estabilidade que permitiu a reconstrução do capitalismo da Europa ocidental e impediu a expansão do comunismo para o hemisfério ocidental, que era o objetivo geopolítico primordial no sistema de divisão de áreas de influência estabelecido com os soviéticos nas conferências de Yalta e Potsdam. A União Soviética reconstruiu a Europa Oriental e suas áreas devastadas pela invasão alemã durante a guerra, mantendo uma estabilidade forçada no marco do sistema comunista comum.

As fronteiras dessas áreas de influência, sempre concentraram as tensões entre as potências, tendo seu exemplo clássico na divisão de Berlin e na fundação de Israel. Mas as grandes fronteiras das áreas de influência eram os territórios coloniais, que tinham soberanias indefinidas. Portanto, as independências africanas e asiáticas ofereciam a oportunidade de mudança hegemônica e, dessa forma, concentravam as tensões entre as grandes potências rivais, transformando a expressão guerra-fria num patético epíteto à hipocrisia intelectual. A guerra entre os Estados Unidos e a União Soviética e seus respectivos aliados, supostamente nunca ocorreu. Devido ao seu potencial nuclear, nunca ocorreu diretamente, 
mas teve inúmeros episódios extremamente graves, em territórios onde a guerra convencional era a regra aceitável, entre forças claramente pró-americanas e pró-soviéticas devidamente apoiadas logística e ideologicamente: Indonésia em 1965 (golpe de Suharto contra o PKI - 500 mil mortos), em Angola (UNITA vs MPLA), Moçambique (Renamo vs Frelimo), FLN Argelina, o governo prósoviético de Nagib Bula vs Talibãs no Afeganistão, os golpes na América Latina etc, para citar apenas alguns exemplos onde a confrontação ideológica esteve na ordem do dia. Nesse sentido, a discussão sobre a grande paz no pós-guerra é parcialmente metafórica e, mais uma vez centralizada nas grandes potências, e não na realidade global.

A prioridade americana foi à estabilização da Europa ocidental, por meio de várias iniciativas de cooperação induzida, como o Plano Marshall, a Organização para Segurança e Cooperação na Europa, a OTAN, a constituição do FMI e do Banco Mundial, GATT, a Aliança para o Progresso de Kennedy entre outras iniciativas hegemônicas para assegurar a estabilidade do ocidente e construir uma ordem no pós-guerra (LIPSON, 1993).

No entanto, quando se fala de um mundo unipolar, e do fim da história ${ }^{2}$, omite-se o fato de que essa ordem foi construída e estabelecida basicamente no mundo ocidental, e as instituições ocidentais não estavam qualificadas para assegurar a estabilidade no mundo todo. O Pacto de Varsóvia, a versão soviética da comunidade de segurança ocidental desapareceu sem deixar traços, ao mesmo tempo em que, a sobrevivência da Rússia como estado herdeiro, mas desprovido da hegemonia soviética, impediu a intervenção, no território da ex-União Soviética e se opôs, sem sucesso, à expansão da influência ocidental em seu antigo condomínio de segurança forçada.

Se utilizarmos o conceito de elaborado por Karl Deutsch (ADLER; BARNETT, 1998), nos anos cinqüenta, de comunidade de segurança, do tipo pluralista, que seria baseada em valores básicos derivados de instituições comuns e responsabilidade mútua, ou seja, uma identidade e uma lealdade comuns. Vemos que essa comunidade existe, basicamente, no ocidente e grande parte do mundo não fez e não faz parte dela, e esta é, simplesmente, a maior parte.

\footnotetext{
${ }^{2}$ Conceito elaborado por Francis Fukuyama no início dos anos 90.
} 


\section{0 conceito de pós-guerra fria: insuficiência de poder e insuficiência institucional}

O final da Guerra Fria representou a abertura de uma caixa de Pandora para a segurança internacional. Tensões étnicas, sociais e políticas represadas pela formidável influência bipolar explodiram com força total, num mundo de paradigmas cambaleantes.

O que surgiu do desaparecimento da ordem bipolar não foi uma ordem unipolar. Ousamos classificá-la de ordem unipolar incompleta, ou fragmentada, na medida em que há um poder claramente superior aos demais e uma proliferação de instabilidades e poderes locais sobre os quais a única superpotência não consegue exercer uma autoridade estabilizadora. A União Soviética exercia um poder estabilizador em sua área de influência, que não foi substituída claramente pela potência remanescente.

Os conflitos étnicos e políticos no Leste Europeu, sobretudo nos Bálcãs, no território da ex-União Soviética, assim como na África, desconcertaram o sistema de segurança com ameaças assimétricas, centradas em múltiplos atores não estatais, com estratégias militares centradas em violações massivas do direito internacional humanitário, representando novas configurações de conflito que expôs a falta de preparação do sistema para pacificar esses conflitos de novo tipo.

A primeira tentativa inovadora ocorreu com a resolução que criou o Tribunal Penal para a ex-Iugoslávia em 1993, que apesar de sua grande respeitabilidade, não deteve a sanha genocida das milícias Servo-Bósnias em Srebrinica no verão de 1995 (RATNER; ABRAMS, 2001).

$\mathrm{Na}$ África, durante a Guerra Fria, as potências premiavam os Estados aliados pela manutenção da ordem e da estabilidade ainda que essas rivalidades tenham alimentado muitos conflitos como o de Angola. No entanto, muitos regimes autocráticos e ditatoriais eram também apoiados em nome da aliança com uma ou outra das superpotências. Não obstante, quando a Guerra Fria acabou, esses países foram deixados ao seu próprio destino. Sem apoio econômico e político externo, muitos regimes africanos não puderam manter seu sistema econômico e sua estabilidade no apego ao poder. Muitos regimes decadentes terminaram de cair e muitos países enfrentaram crises e guerras de caráter político ou étnico. 
Em Ruanda, dois fatos importantíssimos aconteceram meio à tragédia. Foi absolutamente provada a relativa efetividade dos sistemas de alerta antecipada, ou seja, a possibilidade de antecipar com anterioridade razoável o risco de um fenômeno tão complexo como o genocídio. O relator da ONU para execuções arbitrárias, sumárias ou extrajudiciais ${ }^{3}$, B.W. Ndiaye, visitou Ruanda entre os dias oito e dezessete de abril de 1993, onde descreveu os massacres de pessoas da etnia Tutsi como genocídio, e chamou a tomar medidas a respeito em um informe apresentado aos organismos de direitos humanos da ONU, em agosto do mesmo ano. Igualmente, em janeiro de 1994, o comandante da operação de observação dos acordos de paz em Ruanda, UNAMIR, General Romeo Dalaire, obteve evidências de que uma ampla operação de extermínio da minoria Tutsi estava sendo planejada nas mais altas esferas do poder e do governo, com extremistas hutus espalhados por vários setores da vida social, participando ativamente do plano, desde o exército até círculos empresariais (DALAIRE, 2003, p. 143).

No entanto, o que falhou foi a resposta rápida que poderia ter tido um impacto sobre o agravamento do conflito e salvar centenas de milhares de vidas. Quatro anos depois, o Conselho de Segurança fez sua dolorosa Mea Culpa.

O informe do Secretário Geral para o Conselho de $1998^{4}$, elaborado no pico da crise dos Grandes Lagos, reconheceu que a comunidade internacional passou por um período em que superestimou sua nova capacidade de tomada de decisões coletivas e seu suposto aumento do poder de intervenção, devido ao novo grau de consenso entre as grandes potências, principalmente aquelas com assento permanente no Conselho de Segurança. No entanto, a realidade era muito mais complexa que o pequeno clube que herdou o Conselho dos grandes da Guerra Fria, poderia prever e responder.

No começo dos anos noventa, o Conselho de Segurança lançou uma série de iniciativas de intervenção bastante ambiciosas gozando do amplo consenso entre seus membros. O debut da nova policia mundial começou no Chifre da África.

\footnotetext{
${ }^{3}$ E/CN.4/1994/7/11 August 1993 Commission on Human Rights. Fiftieth Session, Extrajudicial, Summary or Arbitrary Executions, Report by Mr. B.W. Ndiaye. Special Rapporteur, on his Mission to Rwanda from 8 to 17 April 1993.

${ }^{4}$ GENERAL ASSEMBLY. Report of the Secretary-General. The causes of conflict and the promotion of durable peace and sustainable development in África. April 13, 1998. Fifty second session. A/52/871 - S/1998/318.
} 
Todavia a missão para o restabelecimento da paz na Somália entre 1992 e 1993 fracassou rotundamente provocando um recuo significativo em todas as propostas de intervenção para o restabelecimento da paz. No ano seguinte, justamente quando uma intervenção mais corajosa e efetiva era esperada diante da mais grave e mais evidente ameaça de conflito atroz em Ruanda, um paralisante estado de letargia prevaleceu.

O informe do Secretario Geral, apresentado à Assembléia Geral e ao Conselho de Segurança sobre a prevenção de conflitos armados em abril de 2001, demonstra toda a fragilidade do sistema. Reconhecendo o papel das organizações regionais, destaca as iniciativas de paz da União Africana e especialmente a intervenção da ECOWAS em Serra Leoa e Libéria, clama pela coordenação dentro do sistema ONU e outros atores como as organizações regionais, Ongs, sociedade Civil e iniciativa privada. Tal ampliação do espectro de parcerias para a segurança internacional não pode ser interpretado de outra forma, que uma demonstração de fraqueza e busca de novos rumos ${ }^{5}$.

As contradições se aprofundaram de tal forma que o suposto aumento do poder de intervenção e o novo grau de consenso entre as grandes potências se esfumaçou em pouco tempo e novas divergências surgiram, dando lugar às duas importantes rupturas da ordem internacional: a intervenção da OTAN em Kosovo em 1999 e a Guerra do Iraque lançada em 2003 à revelia do Conselho de Segurança.

Esse contexto de instabilidade permitiu a expressão das ambições dos países emergentes. No entanto, quem preenche as condições para a tomada de posições no contexto da segurança internacional?

\section{Atores do pós-guerra-fria}

No contexto da segurança internacional, a conceitualização de emergência deve ter características particulares, o que torna a tarefa mais complexa. A constituição da interlocução em matéria de segurança internacional não

${ }^{5}$ GENERAL ASSEMBLY. Report of the Secretary-General. Prevention of armed conflict. June 7, 2001. Fifty-fifth session. A/55/585 S/2001/574. 
corresponde necessariamente ao potencial econômico, ou mesmo militar, na medida em que o uso da força militar direta não necessariamente constitui um elemento fundamental.

Parag Khanna (2008) utiliza o conceito de império para defender a existência de três poderes praticamente iguais no mundo atual onde a economia prevaleceria sobre os outros aspectos. Engano, o poderio econômico não é necessariamente fundível em interlocução e protagonismo em matéria de segurança, ainda que seja um elemento indispensável.

Já Buzan e Waever (2003) utilizam o conceito neorrealista de polarização para determinar que no mundo pós-Guerra Fria restaram: uma superpotência e quatro grandes potências. No entanto, com base nos critérios que delinearemos a seguir, pensamos que o desaparecimento da ordem bipolar deixou uma superpotência e duas grandes potências.

A China e a Europa são claramente potências estabelecidas ainda que não com o mesmo poder e influência que os Estados Unidos. A constituição cada vez mais institucionalizada da União Européia nos faz considerar a Europa como uma entidade única em matéria de segurança internacional. Sua política nuclear é comum, sua participação em missões de paz é coordenada, assim como sua política de segurança. Com as dissidências da Espanha, do Reino Unido e da República Tcheca na questão da guerra do Iraque foi um momento delicado que não afeta esta caracterização fundamental. No entanto, a maior fragilidade devido à fragmentação intestina da Europa como entidade única de segurança, nos impede também de considerá-la como detentora do mesmo potencial dos Estados Unidos.

A presença da China no Conselho de Segurança e seu arsenal militar, tanto nuclear como convencional, sua liderança regional econômica e geopolítica, também a coloca claramente como uma grande potência mundial em matéria de segurança.

A China constituiu um exemplo atípico, uma vez que teve um papel de emergente silencioso durante a Guerra Fria. Seu distanciamento e ruptura com a comunidade de segurança liderada pela União Soviética, com os incidentes de fronteira, a partir de 1961 e a condução de sua própria vertente da Guerra 
Fria no Vietnam e Camboja (este já em aberto enfrentamento com a própria União Soviética), a colocou numa posição autônoma, consolidada com o restabelecimento de relações diplomáticas com os Estados Unidos em 1972, e sua constituição como uma entidade autônoma de segurança. Da mesma forma, utilizando o conceito cunhado por Charles Zorgbibe (2008), a China conduziu sua própria vertente da guerra civil transnacional por meio do apoio aos movimentos de inspiração maoísta, diferenciado e separado da hegemonia ideológica da União Soviética.

Já a Rússia não é a União Soviética, e seu papel se aproxima claramente dos emergentes, ainda que com características particulares como veremos a seguir.

O período que estudamos apresenta grandes transformações e o conceito de polaridade ou das relações centro-periferia explicam apenas parcialmente o atual contexto e deixam grandes lacunas (ZORGBIBE, 2008).

As teorias globalistas acertam ao determinar o caráter global do sistema internacional de segurança, ainda que a crescente importância dos arranjos regionais comece a mudar o eixo de centralidade com que o sistema tem funcionado desde o final da Segunda Guerra mundial.

No entanto, o excessivo foco no aspecto econômico compromete sua precisão no sentido em que ainda o contexto de segurança internacional continua sendo, como dizem os neorrealistas, basicamente centralizados no Estado. No entanto, também é verdade que outros atores somam-se ao contexto da segurança internacional, como a crescente importância dos atores não estatais, como guerrilhas, grupos terroristas, narcotráfico etc. O Estado vem perdendo de forma crescente o monopólio da violência.

\section{Os emergentes no contexto da segurança internacional}

Afinal quem são os emergentes? No contexto da crise do sistema de segurança internacional, novos e velhos elementos devem ser considerados. Consideraremos quatro elementos tradicionais e outro novo: potência econômica, estabilidade política, poderio militar, proeminência regional e legitimidade. Todavia, nenhum elemento prevalece sobre outro a não ser o critério 
de legitimidade que seria ele mesmo um aspecto emergente no contexto da segurança internacional.

O tamanho das economias obviamente tem um valor fundamental em sua influência e respeitabilidade no contexto da segurança internacional. As teorias globalistas chegam a atribuir toda a importância a esse aspecto o que nem sempre é real nos arranjos de segurança que prevalecem no mundo.

Uma prova disso é que grupo dos países mais industrializados do mundo o notório G7 + Rússia (nunca chegou a ser um G8 realmente), não se confunde com o Conselho de Segurança, nem teve grande protagonismo em temas de segurança, tendo-se mantido como um foro essencialmente econômico. O G7 teve discussões importantes na área de segurança quando se tratou do desmantelamento dos arsenais na ex-União Soviética, sobretudo na Ucrânia e no Kazaquistão, no começo dos anos noventa. No entanto, a discussão se tratava majoritariamente sobre os custos dessa operação já que a Rússia vivia uma crise econômica colossal e não possuía os recursos para esse desmantelamento. Não havia conflito, não havia tensão, e a ameaça era controlável, portanto, o aspecto de segurança era secundário.

Porém, dois fatores devem ser claramente remarcados. A Rússia continuou sendo uma potencia militar, mas sua decadência econômica foi notória, durante os anos noventa, quando o PIB decresceu mais de 50\%, sendo inclusive maior que o decréscimo do PIB como conseqüência da II Guerra Mundial, quando grande parte de seu território foi ocupada e o exército alemão chegou a escassos $30 \mathrm{~km}$ de Moscou.

\section{A questão atômica}

Os casos do Paquistão e da Rússia são emblemáticos. O Paquistão pode ser considerado a única potência nuclear de terceiro mundo, com um PIB per capita baixíssimo, e instabilidade política crescente. Crise institucional prolongada, terrorismo e conflitos internos fazem dele mais uma ameaça que um interlocutor em matéria de segurança internacional. Portanto, o poderio militar, mesmo atômico per se tampouco define um emergente em matéria de segurança internacional. 
No entanto, todos os emergentes como o Brasil, a Índia e a África do Sul possuem tecnologia nuclear dominando todo o ciclo do enriquecimento do urânio, e reservas importantes do minério atômico são detidas pelo Brasil. No entanto, ao contrário do Irã, todos esses países buscam construir uma imagem de respeitabilidade e confiabilidade no manejo de suas tecnologias nucleares.

Nem o Brasil, nem a África do Sul possuem arsenais nucleares, sendo que o Brasil estabeleceu um uma comunidade de segurança atômica por meio de um acordo muito mais rigoroso que o tratado de não proliferação de armas nucleares com a Argentina e compartilhamento de tecnologia com fins pacíficos.

A Índia, ainda que tenha arsenal nuclear, sempre manejou esse tema com muito cuidado, tentando construir uma imagem de não ameaça e de potência nuclear pacífica, tentando encapsular sua capacidade nuclear ao contexto defensivo puramente vicinal, sem qualquer pretensão de se impor como potência militar global.

Nesse sentido, aparece um primeiro elemento daquilo que definimos como o fator de legitimidade na definição de emergentes. O sistema de segurança coletiva nunca deixou de ser um sistema global, não representativo e não regional, de salvaguardas da segurança coletiva com base em uma combinação entre capacidade econômica, militar e estabilidade interna. Nesse sentido, o critério da legitimidade aparece como um elemento de aceitação desses novos atores no âmbito de interlocutores já estabelecidos.

Outrossim, as teorias sistêmicas do neorrealismo e as do multilateralismo (RUGGIE,1993) podem ajudar a compreender porque os emergentes não buscam se impor como potências emergentes puramente por meio de demonstrações de poder, mas sim construindo uma imagem de "bom moço", de interlocutores fiáveis e parceiros convenientes na manutenção da paz e da segurança internacionais. Somente uma análise dinâmica, considerando crescente poder (neorrealismo), institucionalidade (liberalismo institucional) e relativo vazio hegemônico (KEOHANE) pode explicar a dinâmica da busca de poder e legitimidade pelos países emergentes no cenário da segurança internacional. 


\section{Tamanho importa?}

Ainda que o ramo da ciência política conhecida como geopolítica tenha se desprestigiado imensamente em virtude de sua utilização pelo nazismo ${ }^{6}$, população e território como fatores de poder militar continuam sendo considerados como elementos importantes. A segurança internacional como um aspecto das relações internacionais ainda mais centrado na figura do Estado faz com que a consideração dele como entidade vivente no espaço físico, humano e geográfico seja relevante se combinada com outros fatores, já delineados. A Indonésia é mais populosa que o Brasil, no entanto, não é possível considerá-la um emergente no contexto da segurança. Sua capacidade econômica e o fator estabilidade política tampouco a qualificam para tanto.

No entanto, parece sintomático que todos os emergentes do sul do mundo, sejam paises populosos, principalmente Brasil e Índia e tenham territórios extensos, abundância de recursos naturais e localizações de relevância estratégica: o Brasil domina, praticamente, toda a margem oriental do Atlântico Sul e ocupa quase a metade do subcontinente; a África do Sul, ocupando o sul da África e as rotas marítimas que historicamente passam pelo cabo da Boa Esperança e a Índia com sua localização privilegiada no Oceano Índico. Igualmente os paises emergentes possuem recursos naturais e capacidade de exploração desses recursos com um setor minerador e energético relevante.

Não existe uma polarização que justifique uma aliança nos mares do sul, nem o domínio sobre os mares é mais um critério definidor de grande potência como nos tempos da armada espanhola. No entanto, é inegável o destaque que esses três paises, além da Austrália, possuem no mapa do hemisfério sul.

Todavia o cenário principal das relações internacionais continua sendo o hemisfério norte, onde territórios e populações estão concentradas. Os países emergentes buscam sua aceitação como atores globais; e sua localização geográfica não possui a mesma relevância que seu tamanho, seu poder econômico e seu poderio militar.

\footnotetext{
${ }^{6}$ KARL, Haushofer utilizou conceitos formulados por F. Ratzel e R. Kjellen (Zeitshirift fur Geopolitik, 1927) e J. MACKINDER (heartland) para racionalizar o expansionismo territorial hitleriano, resumido na afirmação de que a raça alemã estava destinada a levar paz ao mundo através de sua dominação e, portanto as outras nações deveriam assegurar-lhe todo o seu espaço vital, criando o famoso conceito de Lebensraum. A obra de Haushofer é unanimemente considerada como um aglomerado pseudocientífico de "metafísica geográfica".
} 


\section{0 contexto regional}

O contexto regional tem sido, desde a Segunda Guerra Mundial, um elemento importante das relações internacionais, sobretudo a partir dos processos de integração econômica, como a NAFTA, APEC, MERCOSUL e os organismos regionais como a OEA, Conselho da Europa, Liga Árabe e União Africana. Entre as organizações regionais, resta como raro, mas claro exemplo da ANSEAN no sudeste asiático que teve desde o início um claro enfoque de segurança coletiva, no sentido de deter o avanço do conflito ideológico que abarcou o Laos, o Camboja e o Vietnã durante os anos sessenta, setenta e oitenta.

Portanto, poucas organizações regionais têm tido uma clara dimensão de segurança coletiva e, ainda, quando confrontados com uma ameaça regional tem recorrido frequentemente aos organismos globais de segurança, ou às alianças da Guerra Fria como a OTAN e Pacto de Varsóvia, no entanto, mais frequentemente, o Conselho de Segurança. As comunidades européias fundadas com o Tratado de Roma de 1957, com caráter eminentemente econômico e que depois evoluíram para uma estrutura supraestatal, com atribuições claras em segurança coletiva, constituem ainda um exemplo relativamente isolado.

Apesar desse contexto pouco institucionalizado, a constituição de potências militares regionais tem sido uma realidade geopolítica inconteste (FAWCETT; HURREL, 2003). Os acordos bilaterais e a formação de comunidades de segurança regionais têm jogado um papel fundamental. Com a retirada de cena da União Soviética, vários espaços de segurança regional vêm sendo ocupados por alianças regionais.

Sintomaticamente, as três potências emergentes do sul: Índia, Brasil e África do Sul têm tentado jogar um papel de mediador regional de conflitos, sugerindo o caminho da regionalização da segurança coletiva diante dos limites da unipolaridade dos Estados Unidos e das insuficiências do sistema global centrado no Conselho de Segurança. 


\section{IBSA - Os emergentes do sul: Brasil, Índia, África do Sul}

\subsection{Brasil}

O Brasil tem tido uma grande participação em missões da paz das Nações Unidas e tem um dos mais freqüentes históricos de participação como membro não permanente do Conselho de Segurança com nove participações desde seus primórdios uma vez que sua primeira participação ocorreu no biênio 1946-1947 e o último em 2004-2005.

Portanto, durante os 63 anos de existência do Conselho de Segurança, o Brasil esteve presente durante 18 anos, o que inegavelmente significa uma grande familiaridade com os temas tratados pelo conselho e uma razoável respeitabilidade em suas participações uma vez que mantém uma linha de continuidade em sucessivas eleições.

O Brasil tem tido uma aproximação fundamentalmente grotiana das relações de segurança internacional com pinceladas de realismo. Investindo pesadamente no multilateralismo e na legalidade internacional, percebe as disparidades de poder como um elemento desestabilizador em si, combatendo a tendência a unipolaridade e ao unilateralismo americano dos últimos anos. Nesse sentido, tem advogado insistentemente pela reforma do Conselho para torná-lo mais democrático e mais representativo. Portanto, ao não contar com ameaças reais, o Brasil vê a atual estrutura do sistema como um problema de segurança devido às disparidades de poder no contexto global da segurança internacional. Apesar de o Conselho jamais sido pensado para ser democrático, e sim para garantir a segurança, ainda assim, a insistência do Brasil é positiva para ir vencendo as resistências de reforma num sistema fundamentalmente obsoleto.

A vantagem do Brasil em seu contexto regional específico reside na baixa conflitividade da região (América do Sul) nos últimos 30 anos. Guerras interestatais praticamente não ocorreram nos últimos 50 anos, sendo que o último confronto ocorreu em 1995 entre Equador e Peru, que permanece com uma exceção no pós-guerra. O longo conflito na Colômbia que guarda fios de continuidade há um século, com a Guerra dos Mil Dias entre liberais e conservadores terminada em 1903, e em conflito, praticamente, contínuo desde 1948 com o Bogotazo, permanece como o grande desafio. O Brasil, timidamente, tem se aproximado da Colômbia, mas ainda não se constituiu em mediador consistente. 
Da mesma forma, o papel do Brasil como líder da MINUSTAH no Haiti tem sido muito importante, no sentido da confiança depositada pela comunidade internacional na possibilidade de estabilização de um país cronicamente instável desde a caída do regime ditatorial dos Duvalier (Baby Doc) em 1986. Sintomaticamente, a primeira missão comandada pelo Brasil, ocorre dentro de um contexto regional (CERVO; BUENO, 2008). O novo enfoque da MINUSTAH como uma missão de novo tipo, com componentes de direitos humanos e desenvolvimento, aumenta suas possibilidades de sucesso, ainda que reste o desafio de implementar as propostas desse novo tipo de missão de estabilização o que não tem dado mostras de ser tarefa fácil.

Por outro lado, as manifestações anti-Brasil por parte dos governos do Equador, Bolívia e Paraguai são uma conseqüência natural, porém preocupante da emergência do Brasil no contexto global. A estabilidade das relações regionais como aquelas conseguidas com a Argentina de muito maior peso geopolítico, constitui passos estratégicos de grande importância.

O Brasil tem se firmado como potência econômica regional, porém isso não tem se traduzido no contexto da segurança regional, uma vez que o Brasil ainda não se afirmou como uma garante da estabilidade regional. Por outro lado, um reequipamento das forças armadas brasileiras poderia agravar as tendências antibrasileiras no contexto regional com forte presença de regimes populistas.

A parcial obsolescência do arsenal brasileiro e sua pouca preocupação com o poderio militar, lastreado na baixa conflitividade regional e na ausência de ameaças reais, pode ser um elemento pouco favorável à sua afirmação como emergente em matéria de segurança, uma vez que, ainda que a nova ordem não exija o uso da força, esse elemento continua existindo como base para o papel global de garante de segurança e prontidão para prover segurança, em caso de necessidade. Neste sentido, a existência de poderio militar concreto pode ser uma necessidade, e o Brasil não tem se preocupado em reequipar suas forças armadas de forma legitima.

A estabilidade política do Brasil lhe permite afiançar-se como provedor de estabilidade e segurança. No entanto, se pensarmos em termos realistas, compartilhar a região com a única superpotência, não é nada conveniente. No entanto, com tantos problemas globais, os Estados Unidos têm consentido em deixar a região 
livre para a expansão da influência brasileira. Por quanto tempo? Talvez até o desfecho da guerra no Iraque, ou quem sabe quando?

\section{2 Índia}

A Índia, incontestavelmente, constitui uma potência militar de porte médio, possuidora de um arsenal atômico e de tecnologia militar sob controle confiável. Igualmente seu crescimento econômico e sua estabilidade política colocamna em boa situação no contexto global como potência emergente em matéria de segurança.

No entanto, ao contrario do Brasil, a Índia está cercada de problemas por todos os lados, à exceção das belas costas do Oceano Índico.

O Sri Lanka vive uma guerra civil que se arrasta por décadas entre as guerrilhas do norte do país, sobretudo os Tigres da Libertação Tamil e o governo central.

O Nepal, ao norte, elegeu o líder da guerrilha maoísta como primeiro ministro e aboliu uma monarquia absoluta que durava séculos. O Nepal viveu um conflito armado desde os anos oitenta, expulsando milhares de refugiados para a Índia, fragmentando o tecido social e destruindo suas frágeis bases econômicas. A abolição da monarquia absoluta e o pragmatismo dos lideres maoístas, devido à escassa probabilidade de reproduzir uma experiência socialista no atual contexto, pode representar um começo de modernização do Nepal que, no entanto, permanece sendo uma grande fonte de instabilidade.

Bangladesh é um dos países mais pobres do mundo. Povoado por mais de cem milhões de pessoas num território exíguo, sujeito a inundações e furacões durante o período das monções, igualmente é um vizinho instável da Índia. Essa foi a grande responsável pela sua independência do Paquistão em 1971, que foi a causa da terceira guerra entre os dois paises, desde a independência em 1947. No contexto regional, Bangladesh continua instável, pobre, superpovoado e se assemelha muito mais a um fardo que a um aliado.

Por outro lado, o Paquistão viveu muitos golpes militares, o último do general Pervez Musharaf - que, aliás, já deixou o poder - e tem sido um país extremamente instável. Ali Butho, o líder nacionalista extremamente popular foi executado 
pelos militares. Benazir Butho, sua filha e ex-primeira ministra foi assassinada em plena campanha eleitoral, por desconhecidos. O Paquistão tem sido um país que elimina seus líderes de forma quase banal e possui a bomba atômica, o que não é nada banal. O noroeste está infestado de terroristas da Al-Qaeda que goza do apoio de lideres tribais, o fundamentalismo se prolifera incontrolavelmente, inclusive nas áreas urbanas, a economia cambaleia e a revista "The Economist” qualificou o $\mathrm{Pa}$ quistão de o país mais perigoso do mundo. Eles têm razão. Resta saber: perigoso, sim, mas para quem? Certamente para a Índia, mas provavelmente para o mundo todo.

Logo mais ao norte, o Afeganistão, Quirguistão e Uzbequistão dão a tônica da instabilidade regional, com movimentos fundamentalistas em ritmo crescente e instabilidade contínua. O vazio deixado pela União Soviética não será facilmente preenchido pela Índia, laica e democrática, nesses países muçulmanos e autocráticos. A longa confrontação com o muçulmano Paquistão e a ausência de uma composição duradoura, fecha o caminho da Índia ao norte, sempre instável e sempre muçulmano. Poderão tornar-se democráticos, mas dificilmente deixarão sua fé.

A Índia, ou será uma potencia global, ou não será. Para a Índia transcender a região, é muito importante, já que poderia ser reconhecida como líder de segurança regional, somente em termos bastante realistas. A opção do soft power esta virtualmente descartada.

\section{3 África do Sul}

A África do Sul tem poucos recursos para se transformar em emergente global. No entanto, no contexto regional, a exclusão da África da arena global é um certo sentimento de "caso perdido" depois do genocídio de Ruanda, os conflitos do Congo e do Sudão deixam o caminho livre para a África do Sul e a deixam terrivelmente só. Ninguém quer apostar na África, ninguém acredita mais no velho discurso da herança maldita do colonialismo, para os atuais problemas africanos. No entanto, a África do Sul tem poucos recursos, não tem uma economia do tamanho do Brasil ou da Índia, mas não tem opção, ela está na África e a estabilização e crescimento da África é fundamental para sua própria segurança e sobrevivência 
como Estado emergente. A África, por outro lado, não tem opção: ou aceita a liderança sul-africana ou permanecerá no caos. Mas será que sabem disso?

Um fato aleatório que favorece enormemente a África do Sul são seus limites imediatos. Ainda que a África seja a região mais instável do globo, os limites da África do Sul têm gozado de surpreendente estabilidade, a exceção do Zimbábue. Namíbia, Botsuana, Moçambique e Zâmbia têm mantido a estabilidade institucional e crescimento econômico que contrasta com o Zimbábue, imerso no caos econômico e social no marco de uma aberrante autocracia personalista. Apesar das instabilidades dos pequenos Lesoto e Suazilândia, os países adjacentes, Zâmbia, Angola, e Tanzânia, igualmente, têm gozado de estabilidade e crescimento.

O crescimento econômico da África do Sul no final do século XX com a chamada "revolução mineral" levou a um processo de industrialização sem precedentes, com a formação de grandes conglomerados industriais que transformaram a África do Sul no maior produtor mundial de ouro (DOPCKE; HOLANDA MASCHIETTO, 2006). O aumento do preço do mineral no mercado internacional favoreceu imensamente o aumento das rendas de exportação. $\mathrm{O}$ aumento do preço do ouro no mercado internacional foi extraordinário. Entre 1970 e 1980 o preço da onça subiu 600\%, ou seja, de 150 dólares a onça ,em 1970, chegou a 900 dólares por volta de 1980. Entretanto, a mesma abundância em recursos naturais não se converteu em industrialização nos demais países africanos, aumentando a lacuna de desenvolvimento que deixou a África do Sul, praticamente sem competidores no continente africano.

Igualmente, o fato de haver passado de país racista, violento e, eminentemente, agressor a partir das intervenções em Angola, ocupação ilegal da Namíbia e apoio a guerrilha brutal da Renamo em Moçambique, a um país plenamente aceito e participante do concerto africano, numa transição bem sucedida, isso lhe deu imensa autoridade. Se os estados têm personalidades como defende Parag Kanna, a África do Sul se transformou num estado carismático no contexto africano.

O papel da África do Sul como agente desencadeador de irresistível soft power centrado em sua autoridade moral angariada com a transição do Apartheid à democracia, tem-se feito notar nas crises do Quênia e no Zimbábue, onde os arranjos de compartilhamento do poder fazem uma importante experiência de 
estabilização, no marco das fraudes eleitorais que têm marcado as eleições africanas, em que estas têm tido o privilegio de ocorrer. A autoridade moral da África do Sul, como exemplo de ponderação e superação, compensa em parte a sua escassez de recursos para a força militar. Na verdade, o papel desarmado como agente de segurança e estabilização, tem sido muito mais importante e mais construtivo, e a África do Sul tem evitado se envolver militarmente nos conflitos com missões de paz que trazem complicadores e perigos adicionais.

Além desse papel mediador, a África do Sul vem impulsionando o desenvolvimento de uma comunidade de segurança no cone sul da África, no marco da SADC (Southern África Development Community) no qual a agenda de segurança é concentrada no OPDSC (Organ on Politics, Defense and Security Cooperation). No entanto, as iniciativas de mediação unilaterais da África foram imensamente mais bem sucedidas que as operações de segurança desencadeadas pela OPDSC.

O debate a respeito de segurança esteve presente desde os primórdios de fundação da SADC, em Windhoek em agosto de 1992. Esse órgão conta com todos os Estados do Sul da África anteriormente citados e ainda inclui Malawi, República Democrática do Congo e Madagascar. A SADC reconheceu que a questão da segurança regional, vista em termos de pacificação e estabilização, apareciam como pré-requisitos fundamentais para a consecução de seus objetivos primordiais no campo do desenvolvimento.

Portanto, foi em 1996 que o OPDSC foi formado na cúpula de Gaborone, onde a discussão primordial se deu no marco da polarização entre Robert Mugabe e Nelson Mandela. Basicamente, a discussão se deu em torno da independência da OPDSC da SADC. Mandela via os objetivos da OPDSC vinculados e subordinados aos da SADC, mas Mugabe, uma vez constituído como presidente, viu o órgão de segurança como tendo um funcionamento independente das outras estruturas da SADC. Esse impasse, que reflete as diferentes culturas políticas na região, mas se refletiu na disfuncionalidade do órgão, até sua reformulação no começo de 2001.

As respostas às crises da Republica Democrática do Congo em 1997 e aos distúrbios em Lesoto demonstraram toda a fragilidade do órgão e sua crise de autoridade funcional. No momento em que cai o governo ditatorial de Mobuto no antigo Zaire o novo presidente Laurent Kabila que tomou o poder com a ajuda de 
Ruanda e Uganda sofre a dissidência de seus antigos aliados, Mugabe organizou uma sessão do Órgão que declarou a vontade de enviar tropas em nome da SADC, tendo Angola, Namíbia e Zimbábue se comprometido a enviá-las. No entanto, a intervenção não tinha o endosso formal da SADC. Nelson Mandela terminou endossando a iniciativa para preservar a imagem de unidade do órgão, mas condicionou o envio de tropas aos auspícios da ONU.

No caso de Lesoto, tropas sul-africanas e de Botsuana intervieram para restabelecer o Estado de Direito e deter os distúrbios ocorridos depois das eleições de 1998. Ameaçado por manifestações oposicionistas, uma ameaça de golpe de estado militar e latente guerra civil o presidente Mosisli pediu a ajuda da África do Sul, para restabelecer a ordem. A intervenção ocorreu somente após as consultas devidas conforme os procedimentos da SADC, mas a resistência das forcas armadas durante vários dias de confrontação, manifestações públicas contra a intervenção, e erros táticos e estratégicos transformaram a operação num desastre político e militar.

Portanto, o OPDSC teve de ser transformado devido a sua disfuncionalidade inicial, tendo sido firmado um novo protocolo para redefinir seu funcionamento. Muitas das insuficiências que levaram à paralisia e ao fracasso nas intervenções no Congo e em Lesotho foram sanadas, mas a nova estrutura não passou, ainda, pelo escrutínio da realidade.

A África do Sul, sabiamente, tem preferido sua sedução carismática, negociadora e pacificadora ao invés de uma aliança de segurança com as autocracias de Angola e de Zimbábue, principalmente. Em 2008, eleições fraudulentas, repressão e violência, demonstraram que Robert Mugabe não é o melhor parceiro da África do Sul, em matéria de segurança e estabilidade regional. A intervenção negociadora da África do Sul possibilitou, pelo menos temporariamente, que o Zimbábue interrompa sua descida ao inferno.

\section{Legitimidade}

O papel da África do Sul demonstra o quão importante tem sido o papel da legitimidade no contexto da segurança internacional. A prevalência dos direitos 
humanos como norma de conduta para os Estados, das mais diversas composições, tem alimentado o debate sobre a interpenetração dessa última fronteira que constitui o sistema de segurança coletivo.

Apesar dos retrocessos dos anos de combate aos terrorismos, que trouxeram de volta aberrações reputadas erradicadas no contexto da segurança internacional, como a pratica da tortura, as "extraordinary renditions", e o "buraco negro" do direito internacional cavado em Guantánamo, não enfraqueceram a tendência geral e chamaram a atenção para a necessidade de um enfoque da segurança internacional que considere os direitos humanos.

A extraordinária e surpreendente ratificação do tratado de Roma que constituiu o Tribunal Penal Internacional constitui o exemplo mais acabado de que a via da legalidade no uso da forca vem ganhando mais forca, no cenário das relações internacionais. O Tribunal Penal Internacional está jogando sua carta de vida ou morte em Darfur, e os efeitos de sua intervenção em um conflito em curso, determinara sua relevância no futuro próximo.

Sintomaticamente, todos os emergentes aqui citados, à exceção da Rússia, ratificaram o tratado de Roma. Entre os membros do conselho de segurança apenas Inglaterra e Franca, ou seja, a Europa como potência estabelecida integram o tratado. A emergência desses Estados igualmente demonstra a busca por uma maior legitimidade, legalidade e transparência no sistema de segurança coletivo.

O arranjo de 1945 é visto como artificial e elitista, tendo-se esvaziado de conteúdo no sentido de que a atual configuração do Conselho de Segurança não mais reflete a composição do poder político e militar no mundo. No entanto, a ilusão da unipolaridade ainda não sucumbiu à realidade de forma histórica e incontestável. A superioridade inconteste dos Estados Unidos ainda sustenta essa generalização exagerada de seu alcance real.

O Conselho de Segurança vem incorporando a dimensão dos direitos humanos progressivamente, com uma breve desaceleração a partir de 2001, quando dos atentados às torres gêmeas, quando a luta contra o terrorismo passou a dominar sua agenda.

O Sistema foi constituído com seu centro inequívoco na segurança dos Estados nacionais, sem qualquer referencia aos seres humanos. No marco da Carta 
de São Francisco, o tripé: desenvolvimento, direitos humanos e segurança, aparecem pouco relacionados e a segurança aparece, praticamente, divorciada dos demais componentes.

As primeiras tímidas aparições da preocupação com as pessoas aparecem nas resoluções que lamentam as crises humanitárias provocadas pela expulsão dos palestinos na Guerra de Independência de Israel em 1948; no conflito entre Índia e Paquistão: e na Guerra da Coréia em 1950, em que a crise humanitária aparece como elemento subjacente no marco de suas medidas puramente securitárias.

A Resolução 134 sobre o massacre de Shapeville, ocorrido em 1960 na África do Sul, constitui um marco na incorporação da dimensão humana da segurança internacional. O Conselho muda seu enfoque dos problemas puramente internos aos Estados e declara que a situação na África do Sul, ou seja, o do tratamento da população negra poderia afetar a paz e a segurança internacional (ANJOS, 2007). Todas as ações do Conselho tomadas posteriormente, inclusive em relação à ocupação da Namíbia, e a independência da Rodésia do Sul vêm em consonância com esse passo inicial, até a votação de sanções econômicas e o banimento da África do Sul da Assembleia Geral, ainda que jamais tenha sido expulsa da ONU.

A Resolução 688 sobre a situação do Iraque, votada em 5 de abril de 1991, foi muito mais categórica ao afirmar que a violação sistemática de direitos humanos ameaçava efetivamente a paz e a segurança internacional. A atroz repressão do governo Sadam Hussein; as rebeliões xiitas e curdas motivaram a primeira medida militar de proteção de populações civis determinada pelo Conselho; o estabelecimento da zona de exclusão aérea "no fly zone" para a proteção das populações curdas refugiadas em regiões inóspitas nas montanhas entre o Kurdistão Turco e o Iraque. A partir do final da Guerra Fria e das crises que se seguiram, o Conselho viveu uma época de relevância da preocupação com os direitos humanos, apesar dos fracassos, nesse mesmo sentido, que justamente comprometeram a legitimidade do sistema de segurança coletivo.

As resoluções do Conselho sobre as crises da Croácia, Bósnia-Herzegovina, Macedônia e Kosovo refletem uma crescente preocupação pelo destino das pessoas encurraladas nas áreas de conflito. As resoluções sobre Ruanda Serra Leoa, Libéria, Haiti e Timor Leste, todas nos anos noventa, apresentam esse elemento que se 
tornou um componente destacado das preocupações do Conselho de Segurança. Por outro lado, o estabelecimento de dois tribunais penais ad hoc e finalmente a mudança do mandato das missões de paz a partir da MONUC na República Democrática do Congo que deve também proteger populações civis, tenta dar uma resposta aos questionamentos sofridos pela inércia fatal que possibilitou o genocídio em Ruanda.

\section{Missões de paz}

A incorporação da dimensão humana da segurança coletiva avança no sentido de mudar a configuração das missões de paz. Nas missões de paz, mandatos específicos para proteger populações civis, refugiados e deslocados internos, assim como pessoal humanitário passaram a ser componentes essenciais. Um exemplo digno de nota é a MINUSTAH no Haiti, liderada pelo Brasil o qual inclui estabilização, promoção da democracia e dos direitos humanos. Nesse sentido, a constituição da MINUSTAH direitos humanos foi um passo importantíssimo na incorporação dos direitos humanos como parte dos objetivos da missão de paz. No entanto, esse componente tem enfrentado desafios desalentadores em sua parca implementação (TEIXEIRA, 2007). A constituição da EUFOR, a missão de paz para o Chade e República Centro Africana, com mandato incluindo dois países, para proteger refugiados e deslocados internos, marca também o protagonismo da Europa no novo enfoque das missões de paz.

Do sucesso dessas missões dependerá em grande parte a consolidação dos emergentes como interlocutores fiáveis e efetivos no cenário da segurança coletiva e a eventual institucionalização de um novo multilateralismo em matéria de segurança coletiva internacional. Todos os emergentes do sul investem na legitimidade como um componente não somente intrínseco do sistema de segurança coletiva, mas também de sua proposta como aspirantes a esteios da segurança coletiva.

A emergência da doutrina do "Dever de Proteger" que propõe a legalização da intervenção humanitária, igualmente constitui um desenvolvimento interessante, porém controverso. Essa doutrina elaborada por um painel de especialistas, auspiciada pelo Canadá, subordina a soberania à proteção de suas populações (JUBILUT, 2007) e muda o enfoque da segurança do Estado para as pessoas, no 
inovador conceito de "segurança humana" (OLIVEIRA, 2006), pretendendo ser um poderoso instrumento de dissuasão contra o genocídio e os crimes contra a humanidade. A Assembléia Geral terminou por incluir o dever de proteger em sua resolução sobre a reforma da ONU em 2005.

Esse tem sido o ponto de inflexão dos emergentes em sua busca da legitimidade na proteção dos direitos humanos na segurança coletiva. Seu caráter elitista no sentido de que, na prática, pode significar apenas intervenções de países ricos sobre países pobres, e as possibilidades de abuso, devido à ausência de critérios práticos aplicados, ou seja, quando é justificada uma intervenção, como saber se haverá um genocídio ou um crime contra a humanidade, motiva as reticências dos emergentes do sul.

Por outro lado, o Canadá poderia também ser considerado um emergente no sistema de segurança coletiva devido ao seu papel destacado e amplamente superior a todos os outros emergentes no campo doutrinal das reformas no sistema de segurança coletivo. No entanto, o Canadá não propõe reformas estruturais no Conselho como sua ampliação, não tem papel regional de segurança e não pretende um protagonismo no sistema.

O Canadá constitui um caso atípico de relativa renúncia ao protagonismo em matéria de segurança coletiva, ainda que seu papel seja extremamente original e influente. O Canadá só não e um emergente porque parece não querer ser.

\section{G4}

O Grupo do G4: Brasil, Índia, Japão e Alemanha, como aspirantes a integrar o conselho de segurança, constitui outra novidade no contexto do processo de emergência em segurança coletiva.

Apesar do poderio econômico não ser necessariamente fundível com poderio militar e vice-versa, o caso da Alemanha e do Japão coloca elementos de análise complexos. Os dois países possuem considerável arsenal militar e o Japão, particularmente, tem sido um dos países com os maiores gastos militares nos últimos anos. O Japão é o país que mais acumula participações como membro não permanente do Conselho de Segurança. Os tempos são outros, a Guerra Fria acabou, mas 
sobre eles continua pesando o estigma de potências agressoras na Segunda Guerra Mundial. A negativa de reconhecimento do Japão dos crimes cometidos durante a Segunda Guerra Mundial, sobretudo durante a ocupação da Manchúria e na tomada brutal de Nanquim, comprometem sua legitimidade porque colocam em dúvida sua verdadeira renúncia à violência como meio de alcançar poder e influência.

A oposição ferrenha da China a que o Japão integre o Conselho não será facilmente resolvida, principalmente quando a China, como potência militar estabelecida continua aumentando seu poder e influência lastreados, sobretudo em seu formidável crescimento econômico, enquanto que o Japão vem perdendo sua pujança econômica desde a crise asiática de 1997, da qual parece que nunca terminou de se recuperar ${ }^{7}$.

A Alemanha, por outro lado, tem demonstrado um comprometimento com a democracia e com a tolerância notáveis, enterrando o racismo e o expansionismo que marcaram seu papel desestabilizador na Europa durante 50 anos. $\mathrm{O}$ comprometimento da Alemanha com a estabilidade, com a paz e com a segurança, não pode ser questionado, tendo se transformado num esteio de democracia e crescimento no mundo todo, no período pós-guerra. No entanto, a presença firme da Europa no Conselho de Segurança por meio da presença do Reino Unido e da Franca, compromete esta aproximação, ainda que o elemento regional não seja o único fator em jogo nessa disputa global.

No entanto, a iniciativa do G4 pode ter mais desvantagens que vantagens e pode significar mais retrocessos que avanços para o Brasil, e a Índia em seu tortuoso caminho em direção ao Conselho. $\mathrm{Na}$ atual conjuntura, parece que ninguém entrará no Conselho sem o aval da China, e a aliança com o combalido Japão pode custar mais caro do que se imagina.

\section{Irã e o choque de civilizações}

Parece que só quem acreditou em Samuel Huntington foi Mahmud Ahmadinejad.

\footnotetext{
${ }^{7}$ No dia 17 de novembro de 2008 o Japão anunciou oficialmente que sua economia havia entrado em recessão.
} 
O barulhento presidente iraniano entre outras bravatas tem criticado o conselho de segurança por não possuir nenhum representante do mundo islâmico, sendo desqualificado como um instrumento do ocidente para a dominação do mundo, um fantoche do imperialismo americano.

As tensões devido ao programa nuclear iraniano têm sido um ponto de inflexão nas relações com os países da continuamente instável região do Oriente Médio. A conferência sobre o revisionismo do holocausto auspiciada pelo Irã e as declarações escandalosas (de incitação ao genocídio) contra Israel - empurrar os judeus ao mar - não podem ser consideradas normais para um chefe de Estado moderno.

Por outro lado, a liderança regional do Irã é bastante questionável. À exceção da Síria e de movimentos como o Hezbolah e Hamas, o Irã é mais temido que respeitado. O caráter muçulmano tampouco é um elemento de liderança clara. O Islã e extremamente dividido e sunitas magrebinos, jordanianos e sauditas não se sentem automaticamente liderados pelos xiitas iranianos. O nacionalismo árabe constitui outro obstáculo. Todos os povos supostamente (ou realmente) vitimizado pela ação das grandes potências e Israel no Oriente Médio são árabes e inicialmente o nacionalismo árabe foi o grande protagonista das reivindicações do oriente médio e deixou raízes profundas. Neste sentido o Ira não faz parte desta comunidade de identificação cultural, nem fez parte da tradição nacionalista que protagonizou a política regional durante décadas. A interlocução do Irã com o mundo árabe, via Islã é bastante fragmentada para constituir uma verdadeira liderança regional.

No entanto, o parco crescimento econômico do Irã, seus retrocessos sociais e seu papel no financiamento de movimentos que utilizam métodos terroristas como o Hamas, as milícias xiitas do Iraque e outros desestabilizadores como o Hezbolah no Líbano, colocam-no em situação de total ilegitimidade no contexto da segurança internacional.

O Irã continua chamando bastante a atenção e continua fora do grupo dos reais emergentes em matéria de segurança coletiva. 


\section{Paises emergentes: estabilizadores ou desestabilizadores da ordem internacional?}

A questão da emergência de novos atores no cenário da segurança coletiva não tem um valor histórico automático. Não existe qualquer predestinação de que o surgimento de emergentes será estabilizador ou desestabilizador da ordem internacional. Um complexo emaranhado de fatores determinará este aspecto fundamental.

Nesse sentido, a conjuntura histórica, a presença de potências estabelecidas, a configuração do sistema em funcionamento, os aspectos econômicos e, sobretudo, o caráter político desse processo de emergência, determina seu papel estabilizador ou desestabilizador.

\section{Por uma teoria dos emergentes}

A emergência é um fenômeno inegável, palpável, recorrente e histórico. No entanto, não existe uma teoria consistente da emergência nas relações internacionais.

Essa teoria teria que abordar o tema de forma dinâmico, mutante e temporal, tentando identificar suas tendências e justamente seu caráter estabilizador ou desestabilizador em cada contexto histórico. Assim, da mesma forma que restou claro no texto que consideramos o papel dos emergentes do sul Brasil, Índia e África do Sul, como fundamentalmente positivos, descreveremos o caso da Rússia, que consideramos desestabilizador.

O caráter positivo e estabilizador dos emergentes do sul se dá por várias razões entre as quais podemos destacar as principais:

- Não agressividade, busca da legitimidade pela negociação e a cooperação.

- Não demonstração de forca, e sim vontade política pacificadora.

- Papel regional positivo ainda que com níveis de dificuldade diferentes.

- Papel econômico estabilizador e de desenvolvimento regional. 
- Poderio militar essencialmente com fins pacíficos e de garante da paz.

- Comprometimento com o enfoque humanitário e normativo do sistema de segurança.

- Aposta no Soft Power para o ganho de influencia.

Enfim, certamente a lista não é exaustiva, no entanto, a maioria das razões são essencialmente políticas.

No entanto, o fenômeno da emergência de países que colocam seu poder recentemente ganho e sua influência a serviço da estabilidade ainda que com ganhos para si, numa conjuntura de instabilidade em que a única potência não consegue ter um papel estabilizador em todo o mundo, parece-nos um fenômeno fundamentalmente positivo, ainda que não livre de tensões, já que significa a aceitação do multilateralismo forçado pelas potências estabelecidas. No entanto, o caminho à multipolaridade, mesmo com uma grande potência formidavelmente superior, já começou. A presença da Europa e da China já fragmentou o centro de poder no mundo. Portanto, analisando os atuais países emergentes, tentamos interpretar os fatos e desenvolvimentos históricos que refletem a dinâmica de seus movimentos de ascensão e ou expansão no cenário internacional, tomando por enfoque prioritário sua atuação no contexto da segurança internacional, que determinaria reações semelhantes e, portanto, conduzindo a definição de seu papel estabilizador ou desestabilizador da ordem internacional.

Nesse sentido, podemos identificar três tipos interpretações do movimento histórico da emergência que correspondem por sua vez na identificação de três tipos de países emergentes;

- Emergentes substitutivos.

- Emergentes complementares.

- Emergentes reativos.

Os emergentes substitutivos são essencialmente desestabilizadores e irrompem num equilíbrio estabelecido e seu movimento de expansão/ascensão busca substituir lideranças estabelecidas e estáveis. A reação à perda de poder e ao avanço 
substitutivo desse tipo de emergentes tende a desestabilizar a ordem internacional e levar ao conflito.

O exemplo mais típico de emergência substitutiva foi o da Alemanha pósreunificação no século, onde o equilíbrio das potências que garantiu cem anos de paz na Europa, baseado no modelo de estabilidade hegemônica concertada ente as potências européias foi rompido (HOBSBAWN, 2005), ou ameaçado pelo fenômeno da emergência alemã substitutiva. Digo substitutiva, porque não havia espaços ou perda de hegemonia; a ascensão se deu sobre espaços de poder econômico e militar, estabelecidos, nos quais a disputa por colônias e o crescente armamentismo levaram ao conflito. Semelhante, foi a dinâmica ascendente do Japão antes da Primeira Guerra Mundial, avançando sobre a hegemonia decadente da China e Rússia (após a Guerra Russo-Japonesa de 1905), atropelando a influência européia.

Um exemplo de emergência complementar foi o dos Estados Unidos durante o século IXX, em que foi expandindo seu poderio industrial e militar sem substituir, e sem avançar sobre esferas de hegemonia estabelecidas, e sim buscando mercados e expansão militar em áreas onde a influencia européia era parca ou inexistente. Pacífico (anexação do Havaí e Guerra Mexicano-Americana) em outros momentos buscou a substituição, porém as expensas de potências decadentes, como a Espanha, a anexação da Flórida e a independência de Cuba em 1998, assim como a de Porto Rico. Igualmente, auspiciou a independência e anexou a zona do Canal do Panamá em 1903, separando-a da Colômbia, que imersa em uma de suas intermináveis guerras civis, não ofereceu qualquer resistência.

Nesse sentido, os emergentes complementares são aqueles que avançam sem substituir ou sobre espaços políticos de influência decadente, que apenas a institucionalidade restante da hegemonia decadente não pode sustentar indefinidamente. Portanto, esse tipo de emergência cumpre um papel historicamente estabilizador, porque se dá num marco de baixa conflitividade e preenche espaços de poder que poderiam levar a conflitos internos, falência de Estados ou guerra civil prolongada. Quem poderá negar que, em parte, a guerra civil na Bolívia tem sido evitada pelo papel mediador dos países vizinhos e sua negativa de apoiar golpes e outras mudanças inconstitucionais de governo. Potências emergentes regionais substituem o papel que os Estados Unidos deixaram de cumprir na América Latina, devido à perda de influência política e militar. Nos processos de emergência 
complementar, os países tendem a avançar com cuidado, buscando aceitação de seu novo papel, sem tomá-lo por garantido, nem natural.

A emergência reativa apresenta talvez o maior nível de agressividade e efeito desestabilizador, como no caso da Alemanha nos anos trinta. A politização da história, da raça e a humanização do Estado forjam os perigosos conceitos de humilhação histórica e do orgulho nacional. A perda da guerra, os créditos que afundaram a Alemanha num dos processos inflacionários mais profundos da história, a desindustrialização, revoluções proletárias sucessivas, o caos político e social, fizeram surgir uma ideologia reativa de superioridade pela violência da revanche (HOBSBAWN, 2005).

\section{Os russos estão chegando}

O exemplo da Rússia como um fenômeno de emergência desestabilizador salta aos olhos e a pesquisa sobre suas razões nos fornece indicações sobre seu caráter fundamental.

A Rússia apresenta uma combinação explosiva entre perda de poder econômico, instabilidade interna, perda de poder militar, nacionalismo exacerbado, perda de influência regional e crescente autoritarismo político. Os países não aceitam a perda de poder, as populações com nível razoável de identificação com o Estado nacional em que vivem, pressionam os governos que retrocedem, no entanto, o fenômeno da decadência é recorrente e resistido amargamente. Apenas uma reorganização do Estado ou compensações colaterais pacificam estados dilacerados por processos de decadência.

A crise econômica tirou temporariamente a Rússia do cenário decisório em matéria de segurança. A timidez de suas intervenções durante os anos noventa transformou-a, numa potência de segunda ordem, com um arsenal, inclusive nuclear, em decadência e sem manutenção apropriada, o que foi motivo de preocupação para a comunidade internacional.

A Europa principalmente financiou amplamente o desmonte dos submarinos nucleares no mar de Azov e no mar branco que a Rússia não podia manter. Os problemas de segurança internos como os conflitos no Cáucaso (Abkhasia, Ossetia 
do Norte, Ingushetia, e principalmente Tchetchênia); as tensões com a Ucrânia e os atentados terroristas em Moscou voltaram as preocupações de segurança da Rússia para sua própria instabilidade interna. A crise financeira de 1998 terminou de remover a Rússia do cenário internacional da segurança coletiva e, no ano seguinte, a intervenção da OTAN na Sérvia, demonstrou toda sua irrelevância.

A intervenção da OTAN em Kosovo se transformou no auge da humilhação da potência herdeira da ex-União Soviética. A ameaça de veto no Conselho de Segurança devido ao seu apoio histórico ao hegemonismo da Sérvia nos Bálcãs, levou à primeira ruptura do sistema de segurança internacional, quando o uso da força se deu fora da legalidade internacional estabelecida em São Francisco. A Iugoslávia não era necessariamente área de influência soviética, uma vez que o Marechal Iosib Broz Tito, rompeu com Stalin, ainda nos anos cinqüenta. Todavia, o fato de ter sido na área do Leste Europeu o que marca a expansão, de fato, da área de segurança do Ocidente em direção ao Oriente, que seria vista como uma ameaça pelo establishment pós-soviético.

A independência de Kosovo reconhecida apenas por países ocidentais fomenta ainda mais este ressentimento. A incorporação dos países bálticos, da Romênia, da Bulgária e da Polônia na União Européia e seu sistema de segurança, é vista como um estrangulamento da Rússia em seu tradicional mal estar, de estar na Europa sem fazer parte dela.

Durante os anos 90, nas reformas liberalizantes em que a Rússia viveu um processo extremamente contraditório de destruição criativa e destruição pura e simples, o Estado teve de ser financiado pelos novos magnatas multimilionários que financiaram parte do déficit do Estado em troca de ações nas empresas estatais. Dessa forma, grande parte das riquezas do país foi concentrada nas mãos de poucos empresários super-ricos. Ocorre que a maioria deles era de origem judaica, o que fez acender o nacionalismo grão russo e o velho fantasma do antissemitismo (CHUA, 2004). O famoso "Protocolo dos Sábios de Sião" foi forjado na Rússia e foi utilizado por movimentos antissemitas no mundo inteiro durante décadas.

Esse processo choca com o tradicional antissemitismo e com a russificação de séculos de império. Durante o processo de russificação na União Soviética, centenas de russos étnicos foram reassentados nos países vizinhos. A Ucrânia vinha 
sendo russificada desde o império quando era chamada de pequena Rússia (Malaia Rossia). A Latvia, onde a população de língua russa era praticamente inexistente antes da II Guerra Mundial, chegou a 30\% em 1991, ano do fim da União Soviética. Processos semelhantes ocorreram na Estônia, Geórgia, Armênia, Azerbaijão, Uzbequistão, Kazakhstão, e foram aprofundados na Ucrânia.

A política de expansão fronteiriça da União Soviética seguiu o modelo do império russo que optou pela expansão colonial via expansão fronteiriça ao invés de buscar colônias de ultramar como os demais colonialismos europeus. Assim se constituiu no maior país do mundo, no entanto, a Rússia étnica estava reduzida aos arredores de Novgorod, Tvier e Moscou, no século XVI, quando Pedro, o Grande, conquistou a saída ao Báltico e voltou-se para a Europa. As políticas de expansão das fronteiras étnico-culturais e russificação acompanharam o império e manteve uma linha de continuidade com a União Soviética, que anexou os vizinhos bálticos, continuou russificando a Ucrânia e exterminou, na grande repressão, parte de suas minorias nacionais como a polonesa, alemã e chechena que foi deportada de seu território ancestral para o Kazakhstão entre 1944 e 1964 (MARIE, 1996) quando Khruschev lhes permitiu voltar, no período de desestalinização.

Portanto, o fator mais preocupante que contribui para o papel desestabilizador da Rússia no cenário regional continua sendo sua ofensiva de identificação étnica com as populações de língua russa dos países vizinhos e sua utilização como forca expansiva para apoiar seus interesses regionais. O Cazaquistão mudou sua capital para Astana no centro do país, tentando unir sua grande população russa que habita, majoritariamente, o norte do país adjacente à Rússia. A região russófona e pró-russa da Ucrânia também está localizada no sudeste e leste justamente nas adjacências das províncias de Rostov, Smolensk e Kurtsk na Rússia. O atual presidente da Ucrânia é o primeiro presidente pós-soviético de língua ucraniana.

Nesse sentido, a instrumentalização do nacionalismo russo nos países vizinhos e seu expansionismo reativo, ou seja, direcionado a manter o espaço geopolítico que julga lhe pertencer de direito, mas que já não existe de fato, é gerador de estabilização forçada pela violência em suas instáveis fronteiras. $\mathrm{O}$ avanço do Ocidente será detido pela violência e os povos adjacentes pagarão o preço de suas aspirações européias, ou ocidentalistas. As suspeitas de ingerência nos assuntos internos da Ucrânia e a recente invasão da Geórgia têm sido tentativas 
desesperadas de afastar o Ocidente de suas fronteiras. O isolacionismo político e geográfico coloca a Rússia numa posição perigosamente defensiva. A inclusão da Geórgia na OTAN certamente detonaria uma crise sem precedentes.

A emergência da autocracia de Vladimir Putin senta as bases para o estabelecimento de um novo autoritarismo - institucional, dissimulado, porém, com as mesmas conseqüências para a frágil democracia russa. $\mathrm{O}$ assassinato da jornalista Helena Politikovskaya, crítica marcada da atuação da Rússia na Guerra da Chechênia, marca a volta dos métodos de repressão violenta que tantas vítimas fizeram num passado recente demais, brutal demais para repetir-se como farsa. Será uma nova tragédia.

A invasão da Geórgia foi a culminação dessa tendência. Lastreado no unilateralismo dos Estados Unidos, seguiu seu exemplo e usou a força fora dos marcos do Conselho de Segurança ao qual pertence no melhor estilo da guerra fria. O reconhecimento da independência da Ossetia do Sul foi uma provocação aberta e desafiadora, auspiciada pelo erro grosseiro da Europa em reconhecer Kossovo. A integridade territorial foi relativizada em todos os lados pelo Ocidente, então, eles também podem. Reação em cadeia e instabilidade crescente. As disputas com o Ocidente podem levar a Rússia a tentar estabilizar de forma violenta suas fronteiras para garantir sua coesão interna diante da suposta ameaça externa. Isso pode significar mais violência na Chechênia, Ucrânia e Geórgia.

O Neorrealismo ofensivo de John Merchaimer ajuda a entender muito mais essa tendência da emergência reativa nas relações internacionais, que como uma dinâmica geral, nos moldes que ele propõe. Como teoria geral, estará morta, tão logo termine a era Bush, mas continuará vigente para os particulares e intrigantes processos de emergência reativa, ou revanche nas relações internacionais como vem ocorrendo com a Rússia.

Portanto, nem sempre os fenômenos de emergência são estabilizadores, e no caso de potências decadentes, seu desesperado ressurgimento pode ser crescentemente desestabilizador.

Uma teoria da emergência constitui uma tarefa urgente no estudo das relações internacionais. 


\section{0 conselho de segurança}

O pertencimento ao Conselho de Segurança tem se transformado na grande panacéia dos emergentes em matéria de segurança internacional. A reforma do Conselho tem sido vista pelos emergentes, sobretudo os do Sul - Brasil, Índia e África do Sul - como a institucionalização de seu status no concerto das nações. Esse ponto de vista reducionista pode ser a grande armadilha dos emergentes.

A postura do Canadá, silenciosa e influente, demonstra que a reforma do Conselho pode não constituir um fim em si mesmo. O Canadá, sem reivindicar sua integração no Conselho, tem sido muito mais influente em seus rumos, uma vez que vem dando um passo fundamental. Começou a enfrentar o desafio de pensar numa nova doutrina de segurança coletiva que corresponda às necessidades do mundo atual, unipolar incompleto, multipolar desigual, mas fundamentalmente sem uma definição segura sobre si mesmo, que lhe permita pensar em sua própria segurança.

Historicamente, notamos com particular acuidade que o processo de expansão da ONU não correspondeu a uma maior participação nos temas de segurança coletiva. A democracia da Assembléia Geral, na qual o voto de um pequeno país desarmado como o Butão vale o mesmo que o dos Estados Unidos, não guarda qualquer relação com o elitismo do Conselho de Segurança, muito mais realista e muito menos normativo. No entanto, essas discrepâncias guardam estreita relação com a realidade e o normativismo que, nem sempre funciona nos mesmos termos, quando se trata de relações de força, que se situam na fronteira entre o direito e a política e forçam os limites do direito internacional. Os desníveis de desenvolvimento e poder no mundo determinam parte dessa institucionalidade particular.

Em 1945, a ONU contava com a participação de 51 países. Em 1960, já eram 99 países; em 1975, foram 144 países; em 1990, foram 159 países com as adesões de Liechtenstein e Namíbia.

Em 2006, com a adesão de Montenegro a ONU, chegou aos 192 países membros. Ou seja, 141 países, $76,5 \%$ de todos os países do mundo atual, não eram membros quando o Conselho foi estabelecido, mas todos se tornaram membros da Assembléia Geral. Portanto, a discrepância entre o órgão político, democrático e representativo da ONU e seu órgão de segurança mais pragmático e baseada em critérios de poder, estendeu-se de forma notável. 
No entanto, 74 países do mundo, ou seja, 38,5\%, quase metade de todos os países do mundo, nunca foram eleitos membros não permanentes do Conselho de Segurança. Por outro lado, os emergentes refletem uma real, aceita e gradualmente participativa atuação em temas de segurança internacional. O Japão acumula 10 participações como membro não permanente. $\mathrm{O}$ Brasil acumula nove participações; a Argentina, oito; a Índia, Canadá, Colômbia, Itália e o Paquistão, seis participações; a Alemanha, Austrália e Dinamarca, quatro participações. Ou seja, todos os emergentes, sejam participantes do IBSA ou do G4 aparecem como ativos participantes como membros não permanentes do Conselho de Segurança. A única exceção constitui a África do Sul o que pode ser explicado pela sua recente democratização em 1994 e, portanto, recente aceitação nos círculos internacionais de segurança coletiva.

Com efeito, os emergentes buscam a oficialização de um processo de emergência que ocorre não apenas na realidade das relações internacionais, mas tem sido parcialmente institucionalizado pela prática reiterada dos Estados. As contínuas eleições desses países demonstram que o mundo tem confiado neles para resguardar sua segurança, e suas contínuas eleições têm demonstrado consistência e permanência. De certa forma, acumularam maior legitimidade que os membros permanentes que não precisam obter o consenso da comunidade internacional. No entanto, a lógica da segurança nem sempre pode ser vista de forma tão normativa e representativa.

As aspirações dos emergentes, postulando mais representatividade e transparência no Conselho, fazem sentido; porém, num contexto de segurança, importantes relativismos devem ser levados em conta. Segurança e pacificação exigem o exercício de poder formal, capacidade de impor pela força as decisões tomadas em nome da segurança coletiva. $\mathrm{O}$ enfoque democrático e universalista pode ser ingênuo para um mundo pleno de ameaças concretas.

Por outro lado, o exemplo discreto do Canadá deve ser levado em consideração. A reforma do Conselho deve ser efetuada com fins muito além da representatividade, e sim com o intuito de refundar um sistema eficiente de segurança coletiva. A reforma estrutural deve ser acompanhada de uma renovação doutrinária da segurança coletiva internacional, que incorpore sua dimensão humana da prevenção do genocídio e dos crimes contra a humanidade, a estabilidade e as ameaças assimétricas. 
A globalização e o aumento da interdependência econômica torna mister o estabelecimento de um sistema de segurança coletivo condizente com esse fato inexorável. Os genocídios e conflitos anárquicos, as falências de Estados inteiros, as ameaças assimétricas do terrorismo e das criminalidades transnacionais, a crise econômica global que se alastrou como um rastro de pólvora devido à crescente interdependência das economias, demonstram que o tempo da segurança nacional acabou, a única segurança possível é a segurança coletiva.

\section{Por una teoría de los emergentes: países emergentes y seguridad en las relaciones internacionales}

\section{Resumen}

El artículo analisa las limitaciones de las teorías de las relaciones internacionales que tienden a reducir el fenómeno sistémico a las interacciones que ocurren sólo en el sistema central. En general, la literatura hace poca referencia a los fenômenos periféricos o de transición, bien como a la perspectiva de la reconstrucción de una multipolaridad el mundo de hoy. El artículo tiene el objetivo de proporcionar un enfoque inicial de los diferentes tipos de emergencia en el ámbito internacional, centrándose en el aspecto de la acumulación de poder e influencia dentro de la cuestiones de seguridad internacional como la reforma del Consejo de Seguridad, y el papel de los países emergentes como Brasil, Sudáfrica, India y Rusia en particular. El carácter re-emergente de Rusia y sus dinámicas propias son analizados en separado.

Palabras-clave: Seguridad internacional. Consejo de Seguridad. Países emergentes. Concentración del poder.

\section{Referências}

ADLER, Emanuel; BARNETT, Michael. Security communities in theoretical perspective. In: ADLER, Emanuel; BARNETT, Michael (Ed.). Security Communities. Cambridge: Cambridge University Press, 1998. 
ANJOS, Claudia Giovannetti Pereira. Atuação do conselho de segurança da organização das nações unidas nas crises humanitárias na década de 1990. São Paulo, 2007. Dissertação (Mestrado)-Faculdade de Direito da Universidade de São Paulo. São Paulo, 2007. Não publicado.

BUZAN, Barry; OLE, Waever. Regions and powers, the structure of international security. Cambridge: Cambridge University Press, 2003.

CERVO, Amado Luis. Inserção internacional, formação dos conceitos brasileiros. São Paulo: Saraiva, 2007.

CERVO, Amado Luiz; BUENO, Clodoaldo. História da política exterior do Brasil. 3. ed. Brasília: Universidade de Brasília, 2008.

CHUA, Amy. World on fire: how exporting free market democracy breeds ethnic hatred and global instability. New York: Anchor Books, 2004.

DALAIRE, Romeo. Shake hands with the devil. London: Arrow Books, 2003.

DOPCKE, Wolfgang; HOLANDA MASCHIETTO, Roberta. The development of regional security architecture in southern Africa (SADC). In: COSTA VAZ, Alcides. (Ed.). Intermediate states, regional leadership and security: India, Brazil and South Africa. Brasília: Universidade de Brasília, 2006

E/CN.4/1994/7/11 August 1993 Commission on human rights. Fiftieth session, extrajudicial, summary or arbitrary executions. Report by Mr. B.W. Ndiaye. Special Rapporteur, on his Mission to Rwanda from 8 to 17 April 1993.

FAWCETT, Louise; HURREL, Andrew (Org.). Regionalism in world politics, regional organizations and international order. [S.1.]: Oxford University Press, 2003.

FLECK, Isabel. Cúpula de Doha. Correio Braziliense, Brasília, 29 mar. 2009. p. 18

FUKUYAMA, Francis. The end of history? The National Interest, [S.1.], n. 16, summer 1989.

GENERAL ASSEMBLY. Report of the Secretary-General. Prevention of armed conflict. June 7, 2001. Fifty-fifth session. A/55/585 S/2001/574.

GENERAL ASSEMBLY. Report of the Secretary-General. The causes of conflict and the promotion of durable peace and sustainable development in África. April 13, 1998. Fifty second session. A/52/871 - S/1998/318. 
HOBSBAWM, Eric. Era dos extremos: o breve século XX-1914-1991. 2. ed. São Paulo: Cia das Letras, 2004.

HOBSBAWN, Eric. Era dos impérios. 9. ed. São Paulo: Paz e Terra, 2005.

HUGNTINGTON, Samuel P. O choque de civilizações, e a recomposição da ordem mundial. Rio de Janeiro: Objetiva, 1997.

JUBILUT, Liliana Lyra. A legitimidade do principio de não-intervenção em face das resoluções do conselho de segurança das nações unidas. São Paulo, 2007. Tese (Doutorado)-Faculdade de Direito, Universidade de São Paulo. São Paulo, 2007.

KEOHANE, Robert O. After hegemony: cooperation and discord in the world political economy. [S.1.]: Princeton Classic Editions, 2005.

KHANNA, Parag. The second world: empires and influence in the new global order. New York: Random House, 2008.

LIPSON, Charles. International cooperation in economic and security affairs. In: BALDWIN, David A. (Ed.) Neorealism and neoliberalism: the contemporary debate. New York: Columbia University Press, 1993.

MARIE, Jean Jacques. Les peuples deportées de l'union sovietique. [S.l.]: Edition Complexe, 1996.

OLIVEIRA, Odete Maria de (Org). A configuração dos humanismos e relações internacionais. Ijuí: Editora Unijui, 2006.

RATNER, Steven R.; ABRAMS, Jason. Accountability for Human Rights Atrocities. In: INTERNATIONAL law: beyond the nurnberg legacy. [S.l.]: Oxford University Press, 2001.

RUGGIE, John Gerard (Ed.). Multilateralism matters: the theory and praxis of an institutional form. [S.l.]: Columbia University Press, 1993.

TEIXEIRA, Marcella Cunha. Os desafios da Minustah no Haiti. Brasília, 2007. Trabalho de Conclusão de Curso (Graduação)-Centro Universitário de Brasília. Brasília, 2007. Não publicado.

ZORGBIBE, Charles. La communauté internationale dans l'imaginaire des nations. Brasília: Universidade de Brasília, ago. 2008. Aula magna. 